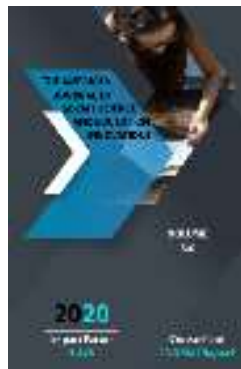

Journal Website: http://usajournalshub.c om/index,php/tajssei

Copyright: Original content from this work may be used under the terms of the creative commons attributes 4.0 licence.

\section{About Nosir Bukhari (A Poet) And His Literary-Scientific Heritage}

\author{
Solijon Komilovich Kurbanov \\ Doctor Of Philology, Professor, The Chair Of The Uzbek Literature Studies, Faculty Of \\ Philology, Andijan State University, Uzbekistan
}

\author{
Akram Akbarovich Khudayberdiev \\ Freelance Researcher, The Chair Of The Uzbek Literature Studies, Faculty Of Philology, \\ Andijan State University, Uzbekistan
}

\title{
ABSTRACT
}

The article provides information on the poet Nosir Bukhari and his literary-scientific heritage, the scope of his work and the ideas made in them.

The social life and modernity problems found illustration in this and that form the poet's works are described by given examples of poems. With the works of Firdavsi, Anwari, Umar Khayyam, Saadi Sherozi, Salman Sovaji, Zahir Faryabi and Nasir Bukhariy's works by given samples of the harmony of the ideas as well as the themes in poetry are shown.

\section{KEYWORDS}

Devan, ghazal, mysticism, wine, love, beloved, dervish, zahid (godly, pious), unity(vahdati vujud), spirit and body.

\section{INTRODUCTION}

Our compatriot Nosir Bukhari is one of our great representatives of the classical literature of the XIV century. His birth date is unknown. The date of his death also varies in different historical sources as 722/1370, 773/1372, 779/1377. There are the following lines in the dedication poem dedicated to Sultan Uvays in his divan:

Сол бар хафтсаду хаштоду ду аз хижрат буд, К-ин муборак басар омад ба тариқи эъжоз. $[6,42 \mathrm{a}]$ 


\section{Meaning :}

It was seven hundred and the eighty-second Hijri (Anno Hegirae) year.

In short, I have come to even this blessed year. Hence, the poet was still alive in 782 (1380-1381 $\mathrm{CE})$. This overrides all of the dates in the above sources. The poet's divans which are kept in the libraries of Namangan, Tashkent, Dushanbe, St. Petersburg, Tehran, the masnavi called "Hidoyatnama", the rubaiis and his dedications show that he was a perfect, highquality poet.

The poetic legacy of Nosir Bukhari is preserved in more than 10,000 pairs of lines (so-called "bayt"). Social life, the issues of that time are reflected in one way or another in them and they provide very good examples of all the genres of poetry that have ever existed in our classical literature. From them one can feel the styles of Firdavsiy, Anvari, Omar Khayyam, Saadi Sheraziy, Salman Savajiy and Zahir Faryabiy.

Носир аз гуфтаи Саъдий ба тариқи тазмин, Арза дех, гарчи сўхан меравад аз тарзи Захир. $[6,42]$

\section{Meaning:}

Nasir, represent what Saadi said as an imitation,

Although your words come from the Zahir style.

Jan Ripka, one of the European scholar Orientalists, evaluated as "The ideological content of Hafiz's work is as close as his contemporary friend Salman Sovajiy's friend Nosir Bukhari (date of his death 1377-78)" in his book called "History of Persian and Tajik literature". Indeed, as we look through the divans of both poets a number of bayts and ghazals written by them are close and harmonious.

\section{For example, Nasir Bukhari:}

Масжиду майкада дар мулки Худо ин хаме хаст

Фисқу пинхоний зухди бериё ин хаме хаст. $[6,79]$

\section{Meaning:}

All existing from mosque to groggery are all the property of God,

Cruel secrets and hypocritical piety is all that exists.

\section{Hofiz Sherazi:}

Хосили коргахи кавну макон ин хаме нест, Бода пеш ар, ки асбоби жахон ин хаме нест,

\section{Meaning:}

Existence and absence of the world is nothing. Bring the wine, the matter of the world is nothing.

Iranian scientist Muhammad Taqhi Bahar published Nasir Bukhari's ghazal and shows that this ghazal is in harmony with Hafiz Sherazi's ghazal in his article in the journal "Sohan". The scientist noted that this ghazal might have been written as a response.

Davlatshakh Samarqandiy wrote as followings in his famous work named "Tazkirat ushshuaro": "Darvesh Nasir Bukhari, may Allah's mercy be upon him, he was a virtuous man, and his poems were never free from truth. Poverty smelled in his words. He was always in a dervish dress.

He had nothing but his earthly hat, a wearing (so-called chapan), and books.

The great poet and thinker Alisher Navoi mentioned in his book "Mahbub ul-Qulub" that Nasir Bukhari was one of the most famous poets of that time: "There are several poets 
who worked on the literature of mysticism. They are Hodja Kirmani and Mawlana Jaloluddin and Hodja Kamal and Anwar and Zahir and the captives and Salmoniy Sawazi and Nasir Bukhari and Secretary Nishopuri and Shahigi Sabzawari" [4,117].

The book on the theory of poetry named "Mukhtasar" by Zahiriddin Muhammad Babur contains more than 60 names of the poets of the XIV-XVI centuries. Namely, it was given Nasir Bukhariy's ghazal, which begins with the words "Parishonam chu zulfat kholam in ast". Abdurahman Jami in his book "Bahoristan", written in 1487 , says, "Nosir, thanks to him, he is one of the poets of Movarounnahr, from Bukhara. His poems contain mysticism".

Indeed, during the 13th-14th centuries, mysticism had reached its peak in both theoretical and practical terms. The flourishing of mysticism literature also came at that time. Many poets express secularness together with divinity in their creations. The beauty of the world is reflected as a shadow of divine beauty in the works of Fariduddin Attor, Anvar, Omar Khayyam, Saadi Sherozi, Nasir Bukhari, Hafiz Sherozi, Kamal Khojandi, Jami and Navoi. The following lines of Nasir Bukhari are an example of this:

Ки жахон пураст аз рухи дўст, Жумлаи коинот сояи ўст. [6,77]

\section{Meaning:}

The world is full of friends, The whole universe is its shadow.

Or:

Хама туиву туро дар хама намеёбам, Жахон пур аз ту, туро дар жахон намеёбам. $[6,77]$

\section{Meaning:}

In all things you go, but I cannot find you,
The world is full of you, but I can't find you in the world.

Or:

Оинаи Худойи рухсори туст моро, Бигзор то бубинам дар оина Худоро. [6,77]

\section{Meaning:}

Your face is a divine mirror for me, Let me see God in this mirror.

The poet now concludes that the soul has become a "mirror of the world", that is, falling in love. Thus, Nasir stands firmly in the position of the philosophical flow called "Vahdat ulVujud". According to him, the universe and man, that is, the spirit and the body, the body and the spirit are united.

For a poet who is in love with Allah, who burns for him, the Sharia laws are all unnecessary. For example:

Дигар аз Носир хадиси жаннату дўзах мапурс,

Дўзахи мо хажри ёр асту висолаш жаннат аст. $[6,97]$

\section{Meaning:}

Do not ask Nasir about the story of hell and paradise,

My hell is apartness from the beloved and my paradise is being with the beloved.

Alisher Navoi calls them that they are such people who are superficial and deprived of independent thought, imitating the doctrines meaninglessly.

Зохид, сенга хуру менга жанона керак, Жаннат сенга бўлсин, менга майхона керак. $[6,75]$

\section{Meaning:}

Prayer, you need angels and I need my Beloved, Paradise is for you and groggery is for me.

Nasir Bukhari, in harmony with the ideas of Omar Khayyam, has beautifully illustrated that 
after a person dies, he joins the dead bodies of the material world. Nasir, who has never had succeeded his beloved in his life, believes in the fact that after his death, a jug will be made from his skull, and then his beloved will put her lips on his lips while drinking water in this jug: Дорам умеди он ки лабат бар лабам расад, Рўзе ки косайи сари Носир сабў куни. $[6,160]$

\section{Meaning:}

One day when you made a jug from Nasser's skull,

I hope my lips will reach her lips.

According to the poet, the world is a mirror made of the desire to look at his beauty, loving himself of the single eternal spirit. The light spread by the explosion of the primary power is reflected in the mirror, that is, all creations in this material world - from the rays to the sun, from the earth to the sky and the whole planets - are lit by this very light. They move through this light and evolve within a certain harmony. The poet accepted this divine reflection through a model of wine. The material world is a glass or a cup according to mysticism. The poet sees the light of God (beloved) through both the cup and the poison.

Mysticism is such a great doctrine which has no contradictions and which denies hypocrisy and arrogance, claim and greed that poets can inspire with it.

The poet, who has gained much experience in life, pays special attention to the use of each word in their proper places. He believes in the power of the word and says that it is possible to cure man by the help of the sweetness of the word. He condemns the rigidity and rudeness of the word:

Носир забон дароз макун кон зиёни туст,
Як нуқта бар забон чу фазойи, шавад зиён. $[6,134]$

\section{Meaning:}

Nasir, do not stretch your tongue, it will hurt you.

Putting a single point to the word "language" is "damage".

He strongly condemns the possession of property taken by harming a person, saying "Do not take worldly possessions, hurting someone. He honors human dignity and believes that nothing can be compared to a great name like "Man" on earth.

Unlike some of the members of other doctrines, Nasir al-Bukhari explains by saying "g'ami olam maxo'r ey dil" (67), that is, "Oh soul, do not worry about the world" and by this one can understand that everybody should be with God and be among the people and live their lives enjoying joys and only one life given to man in this world.

Nosir Bukhari is a singer of prosperity, purity, honesty, beauty, justice, truth, perfection. He promoted the idea of honoring human life, making life worthwhile, living wisely, acquiring knowledge, controlling one's self, and in a word, spiritual perfection.

\section{REFERENCES}

1. Abdurahman Jami. Spring. Con Light, 1903.

2. Alisher Navoi. Devon. Volume 1. State Publishing House of Uzbekistan, 1948.

3. Alisher Navoi. Works. Volume X. Tashkent. Science, 1966, p.214.

4. Alisher Navoi. Works. Volume XIII. Tashkent. Science, 1996.

5. Davlatsheikh Samarkandiy. Tazkirat ushShuaro. p.275. Uz Academy of Sciences. 
Doi: https://doi.org/10.37547/tajssei/Volumeo2Issue09-20

Institute of Oriental Studies. Handwriting 1.

num.: 2119.

6. Devoni Nasir Bukhari. Sheroz. $858 \mathrm{~h}$.

7. Hasanov S. "The Summary". P.1972.134.

8. Institute of Oriental Studies of Academy of Sciences of Uzbekistan, publishing, inv. 22706.

9. Institute of Oriental Studies of Academy of Sciences of Uzbekistan. Manuscript No. 2236.

10. Jan Ripka. History of Persian and Tajik literature. M. Progress, 1970 p. 107.

11. Magazine literature, doneshu, emruz "Suhan" p. 1441347. 